\title{
Liver Glutamine Synthetase Activity and Glutamine Levels in Blood and Tissues in Chickens Fed Various Levels of Dietary Protein
}

\author{
Yutaka Karasawa*, Masako Horil, Eiichi Mryazawa, \\ Sachiko Tahara and Takanori Aramaki \\ Department of Animal Science, Nippon Veterinary and Zootechnical \\ College, Musashino-shi, Tokyo 180
}

(Received May 1, 1978)

\begin{abstract}
Glutamine synthetase activity in the liver and glutamine levels in the blood, liver and kidney were measured in the cockerels fed 0,5,20 and 40\% protein diets. All the chickens gained in body weight and total urinary nitrogen excretion increased linearly with protein intake. Liver glutamine synthetase activity increased with an increase of the dietary protein level. On the other hand, plasma glutamine concentration decreased with the increase of the dietary protein level, and liver glutamine concentration also responded to the changes of dietary protein level of more than 5\%. Ammonia levels in the blood and urine increased linearly with the increase of the dietary protein level. Renal ammonia concentration also responded similarly to dietary protein level of more than $5 \%$, whereas ammonia concentration in the liver showed almost the same level except for $20 \%$ protein diet feeding. The increased activity of liver glutamine synthetase and the increased ammonia production in the high protein feeding suggest that glutamine formation is greater in the chicken fed the high protein diet than in the chicken fed the low protein diet. Nevertheless, glutamine accumulation in the blood and tissues was rather small in the chickens fed the high protein diet. Uric acid concentration in the blood, liver, kidney and urine increased in proportion to the dietary protein level, and in all the dietary protein levels used here renal uric acid level was significantly higher than hepatic uric acid level. The more active synthesis of uric acid may partly account for the low concentrations of glutamine in the blood and tissues when the high protein diet was fed to chickens, since glutamine donates two of four nitrogen atoms of uric acid.
\end{abstract}

Glutamine $^{1,2)}$ donates two of four nitrogen atoms of uric acid, which is a major end product of nitrogen metabolism in the chicken. Ammonia is also used in place of glutamine for the synthesis of 5-phosphoribosylamine, the first intermediate of uric acid synthesis ${ }^{3-5}$ ). Therefore, glutamine formation and ammonia production have a close relation to uric acid formation in the chicken.

Uric acid in the blood plasma $a^{(6,7)}$, tissues ${ }^{(6)}$ and excreta ${ }^{7-9)}$, and activities of enzymes ${ }^{(0)}$ involved in uric acid formation increase with an increase of dietary protein level in the chicken. Ammonia also increases in the blood ${ }^{6)}$, tissues ${ }^{6)}$ and excreta $^{8,9)}$ as a dietary protein level increases. These

*Present address: Laboratory of Animal Nutrition and Feed Science, Faculty of Agriculture, Shinshu University, Ina-shi 396.

Jap. J. Zootech. Sci., 49, (12): 872-879.

1978. 12 . 


\section{Glutamine Synthetase and Glutamine Levels}

facts support the close relations of uric acid formation to ammonia production in the chicken. On the other hand, it has not been specified how glutamine levels in the blood and tissues and glutamine synthetase activity responed to varying levels of dietary protein in the chicken, although it has been found that the plasma glutamine concentration ${ }^{11}$ ) is lower and liver glutamine synthetase activity is higher ${ }^{12.13)}$ in the chicken fed a high protein diet than in the chicken fed a low protein diet.

In the present experiment, liver glutamine synthetase activity and glutamine levels in the blood, liver and kidney were examined in the chicken fed various levels of dietary protein.

\section{Materials and Methods}

Day-old Single Comb White Leghorn male chicks from a commercial hatchery were raised on a commercial diet, and the 5-month-old cockerels thus obtained, weighing about $2 \mathrm{~kg}$, were housed in individual cages and fed $35 \mathrm{~g}$ of an experimental diet per kilogram of body weight once a day (9:00 AM) for 5 days. The diet offered was consumed within 40 minutes in all cases. Water was freely available.

The $0,5,20$ and $40 \%$ protein diets used in this experiment contained $0,6.3,25.2$ and $50.4 \%$ of egg albumin as the sole source of protein at the expense of cornstarch, respectively. The proportion of other ingredients than egg albumen and cornstarch was the same in all the diets. The composition of the $0 \%$ protein diet was as follows (\%): cornstarch, 87.38 ; cellulose powder, 3. 50; corn oil, 2.00; mineral mixture ${ }^{14)}, 5.63$; vitamin mixture ${ }^{14)}, 1.22$; choline chloride, 0.27 .

Heart, portal vein and ureters were catheterized in the same manner as described previously ${ }^{11}$. The cardiac and ureter catheters were used for the collection of blood and urine, respectively. To make urine collection easy, $5 \%$ glucose solution was infused at a rate of $0.556 \mathrm{~m} l$ per minute through the portal catheter, at 6 hours after feeding on day 5. This infusion did not appreciably affect the levels of nitrogen compounds in the blood, liver, kidney and urine as well as liver glutamine synthetase activity determined in this experiment because blood nitrogen constituents showed almost the same level before and after the infusion. Blood sample of $3.5 \mathrm{ml}$ was obtained through the cardiac catheter just before the infusion and 1 hour after the infusion, and total urine was collected during the infusion. After the second sampling of blood, experimental birds were killed, and liver and kidney were quickly removed and stored at $-20^{\circ} \mathrm{C}$ until analyzed.

Uric acid in the blood plasma and urine was determined by the ultraviolet spectrophotometric method ${ }^{15,16)}$. Plasma glutamine and blood and urine ammonia were determined by the method described by GoLDsTerN $\left.{ }^{17}\right)$ and by the colorimetric method ${ }^{18)}$, respectively. Glutamine, ammonia and uric acid in the liver and kidney were determined as previously reported ${ }^{19}$. Liver glutamine synthetase activity was measured by the method of Sellinger and De Balbian Verster ${ }^{20}$. One unit of the enzyme activity is defined as the amount of enzyme causing the formation of $1 \mu$ mole $r$-glutamyl hydroxamate in 60 minutes.

\section{Results and Discussion}

All the chickens fed the $0,5,20$ and $40 \%$ protein diets gained in body weight (Table 1). Liver weight decreased with an increase of dietary protein level, whereas kidney weight tended to increase with protein intake when dietary protein level was more than $5 \%$ (Table 1 ). The response of liver weight to the increase of dietary protein level is different from that reported by OKUMURa et al. ${ }^{21}$. Using growing chicks as an experimental animal and whole egg powder as a dietary protein source, they observed an increase in liver weight when a higher protein diet was 
Table 1. Weight of body, liver and kidney in the chicken fed various levels of dietary protein.

\begin{tabular}{|c|c|c|c|c|}
\hline & \multicolumn{4}{|c|}{ Dietary protein level (\%) } \\
\hline & 0 & 5 & 20 & 40 \\
\hline Body wt. gain ( $\mathrm{kg} / 5$ days) & $\begin{array}{c}0.03 \pm 0.00 \\
(20)\end{array}$ & $\begin{array}{c}0.10 \pm 0.00 \\
(21)\end{array}$ & $0.11 \pm 0.00$ & $\begin{array}{c}0.14 \pm 0.00 \\
(19)\end{array}$ \\
\hline Liver wt. (g/kg BW) & $\begin{array}{c}19.7 \pm 0.5 \\
(24)\end{array}$ & $\begin{array}{c}\text { 17. } 3 \pm 0.4 \\
(21)\end{array}$ & $\begin{array}{c}15.6 \pm 0.6 \\
(9)\end{array}$ & $\begin{array}{c}14.9 \pm 0.3 \\
(19)\end{array}$ \\
\hline Kidney wt. (g/kg BW) & $4.1 \pm 0.1$ & $\begin{array}{l}3.8 \pm 0.1 \\
(19)\end{array}$ & $\begin{array}{c}4.4 \pm 0.1 \\
(9)\end{array}$ & $4.9 \pm 0.1$ \\
\hline
\end{tabular}

Values are means \pm SEM with the number of chickens in parentheses.

fed to the chickens. In spite of the changes in tissue weight by the dietary protein level observed here, tissue levels of nitrogenous compounds per unit weight and those per whole organ showed similar patterns in response to varying levels of dietary protein. Therefore, the data on the contents of ammonia, glutamine and uric acid in the liver and kidney are expressed in terms of the content per unit weight in this experiment.

Total urinary nitrogen increased linearly with protein intake as reported by other workers ${ }^{8,9)}$ (Fig. 1A). This indicates that nitrogen catabolism is more active in the chicken fed a higher protein diet.

As shown in Fig. $1 \mathrm{~B}$ and $\mathrm{C}$ ammonia levels in the blood and urine significantly increased with an increase of dietary protein level. The similar results have been reported by TASAKI and Okumura ${ }^{8)}$ and Teekell et al. ${ }^{9}$ with urine and by Okumura and TasakI ${ }^{6}$ ) with blood. Renal ammonia concentration also increased in proportion to the dietary protein level from 5 to $40 \%$ (Fig. $1 E$ ), whereas liver ammonia was almost the same level on all the diets except for $20 \%$ protein diet (Fig. 1D). On the other hand, ОкUмURA and $\mathrm{TASAKI}^{6}{ }^{6}$ have shown that ammonia contents in both liver and kidney gradually increased as dietary protein level increased. The discrepancy between their results and the data obtained here is unexplained. Activities of glutamate dehydrogenase, alanine transaminase and aspartate transaminase, which are the most important enzymes in the production of ammonia in the chicken body, increase in the quail liver in response to the high protein feeding ${ }^{223}$. In view of the raised activities of the enzymes involved in ammonia production and the increased ammonia levels of blood, kidney and urine observed here, it could be assumed that ammonia production in the chicken increases proportionally to the dietary protein level. However, ammonia concentration in the liver did not increase even when high protein diets were fed to chickens. This may be explained partly by the rapid removal of ammonia from liver and partly by the active consumption of ammonia for glutamine synthesis. Karasawa and $\mathrm{T}_{A S A K \mathrm{I}^{2.3)}}$ have shown that liver is a major site of glutamine production from glutamate and ammonia.

WiLson et al. ${ }^{241}$ with chickens and $\ddot{O}_{\text {RSTRöM }}$ et al. ${ }^{25)}$ with pigeon liver slices indicated that glutamine formation was the major fate of exogenous ammonia. KARASAWA and $\mathrm{T}_{A S A K I^{26}}{ }^{2}$ and $\mathrm{KA}^{-}$ RASAWA $^{27,28)}$ have also observed the marked increases in plasma and liver glutamine levels in the chicken infused with ammonia. These findings suggest that glutamine formation become great when large amounts of ammonia are present in the chicken body. The data shown in Fig. 1 indicate that the more the protein is taken the more the ammonia is produced in the chicken body. The present experiment further indicates that the activity of liver glutamine synthetase, 

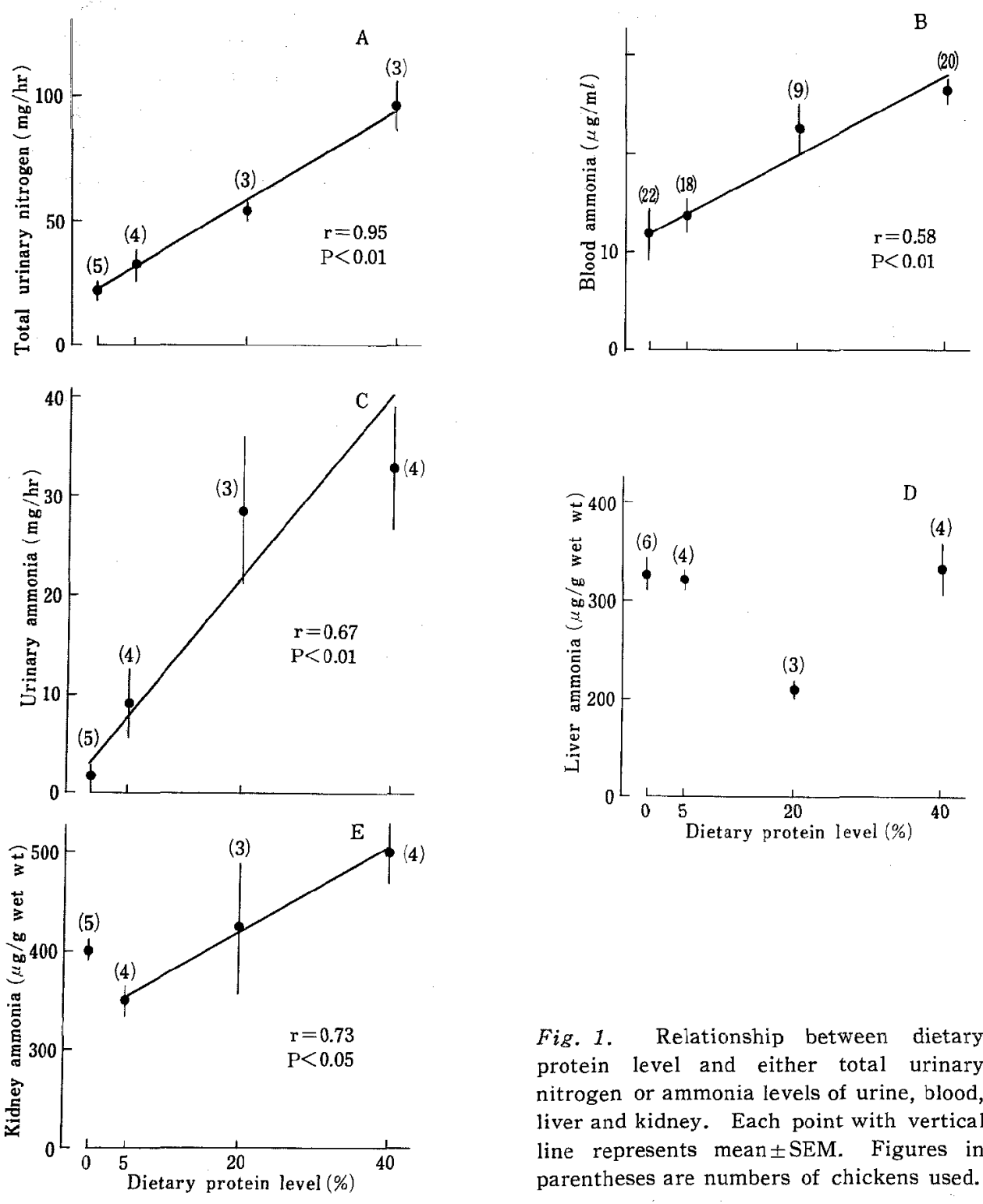

Fig. 1. Relationship between dietary protein level and either total urinary nitrogen or ammonia levels of urine, blood, liver and kidney. Each point with vertical line represents mean \pm SEM. Figures in parentheses are numbers of chickens used. 
which is participated in the reaction of glutamine formation from ammonia and glutamate, increased with an increase of dietary protein level (Fig. 2A). Katunuma et al. ${ }^{12}$ ) and HoRn and FEATHERSTON ${ }^{13)}$ also observed that liver glutamine synthetase activity was high in the chicken fed a high protein diet as compared with that in the chicken fed a low protein diet. From these data glutamine formation is assumed to be increased with an increase of dietary protein level in the chicken. In spite of such an assumption, glutamine concentration in the blood plasma linearly decreased with an increase of dietary protein level (Fig. 2B). Liver glutamine contents similarly decreased with an increase of dietary protein level of more than 5\% (Fig. 2C) and the similar response was observed in kidney glutamine content although not significant (Fig. 2D). KaRASAWA et al. ${ }^{11}$ have observed a lower concentration of plasma glutamine in the chicken fed a high protein diet than in the chicken fed a low protein diet, and they suggested that the
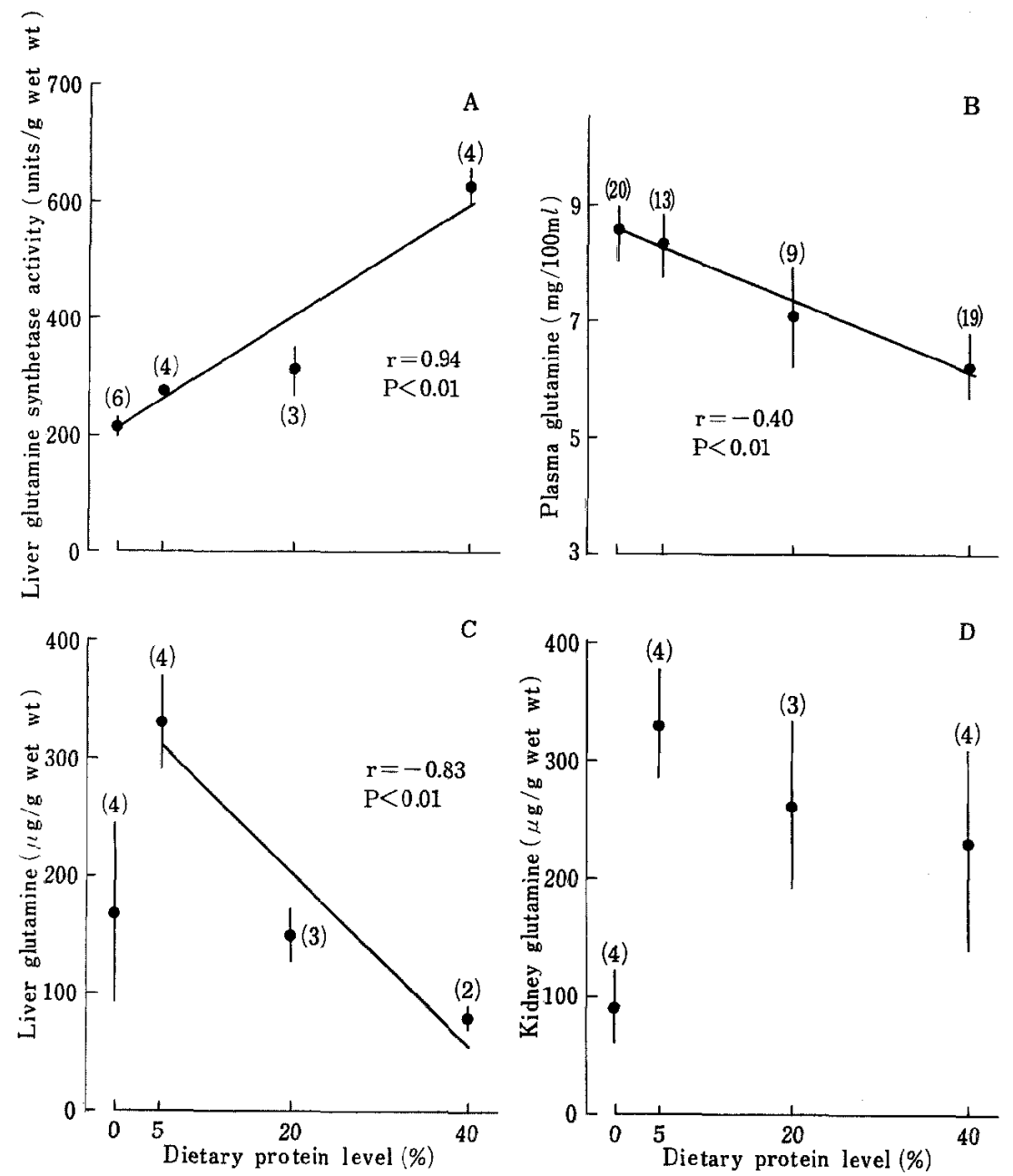

Fig. 2. Relationship between dietary protein level and either liver glutamine synthetase activity or glutamine levels in the blood plasma, liver and kidney. Each point with vertical line represents mean \pm SEM. Figures in parentheses are numbers of chickens used. One unit of enzyme activity refers to the formation of $1 \mu$ mole $\gamma$-glutamyl hydroxamate in 60 minutes. 


\section{Glutamine Synthetase and Glutamine Levels}

conversion of glutamine to other compounds was more rapid in the chicken fed the high protein diet than in the chicken fed the low protein diet.

As shown in Fig. 3, uric acid levels in the blood plasma, urine, kidney and liver increased linearly with an increase of dietary protein level. Many workers have also reported that uric acid levels in the blood plasma ${ }^{6,7)}$, excreta ${ }^{7-9}$ ) and tissues ${ }^{6}$, and activities of enzymes ${ }^{10)}$ involved in uric acid synthesis increase with an increase of dietary protein level. The more active synthesis of uric acid may partly account for the low concentrations of glutamine in the blood and tissues when the high protein diet was fed to chickens, since glutamine donates two of four nitrogen atoms of uric acid1.2).

In all the dietary protein levels used here, uric acid concentration. was significantly lower in the liver than in the kidney $(\mathrm{P}<0.05)$. $\left.\mathrm{CHOU}^{29}\right)$ also reported a similar result in the chickens of different ages, but OKUMURA and $\mathrm{TASAKI}^{6>}$ did not observe such a difference. These conflicting
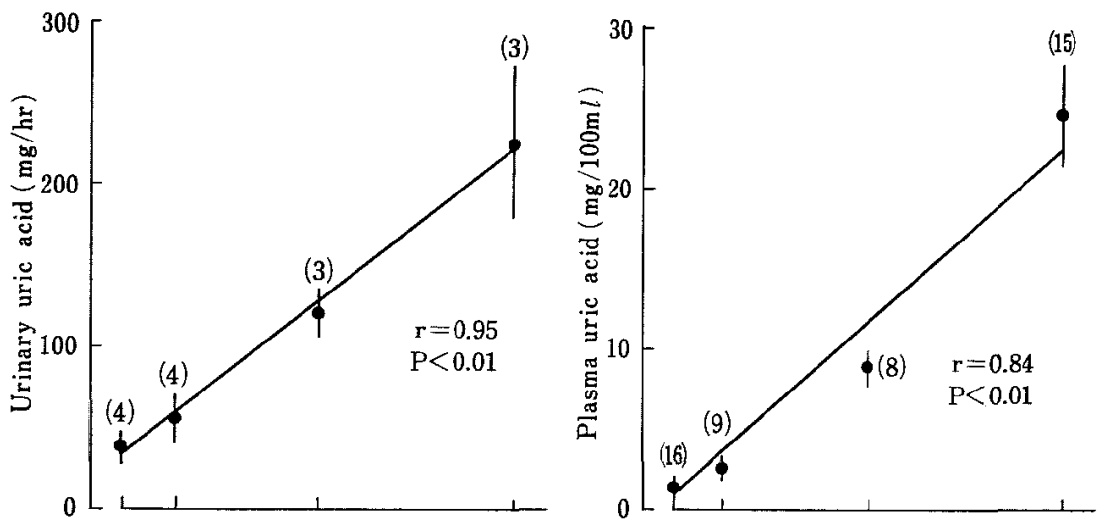

C

$\mathrm{D}$

(4)
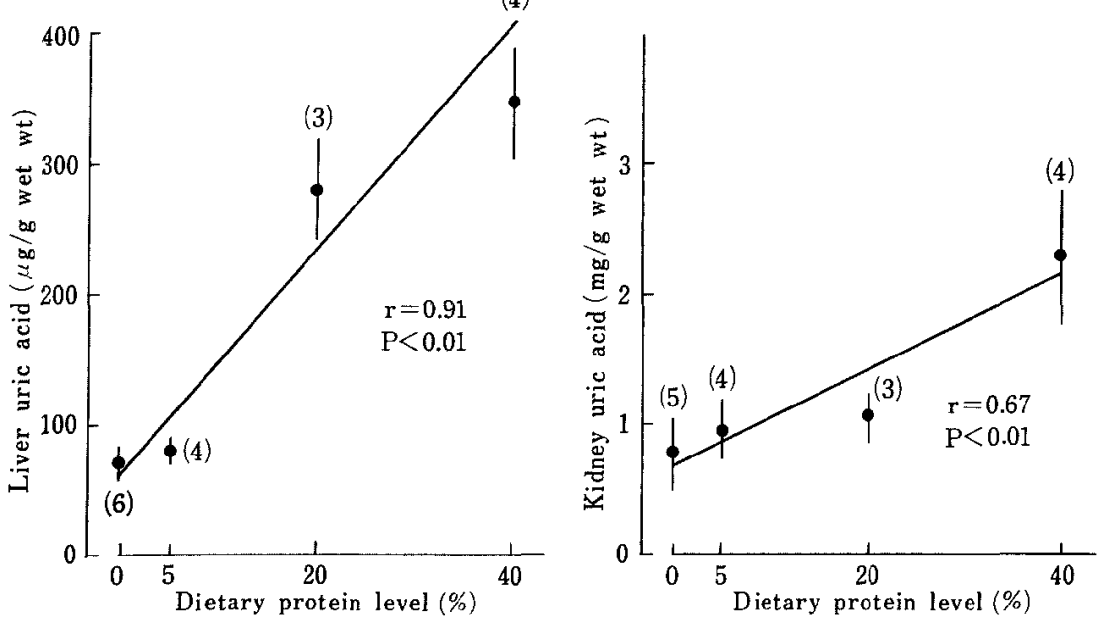

Fig. 3. Relationship between dietary protein level and uric acid levels in the urine, blood plasma, liver and kidney. Each point with vertical line represents mean \pm SEM. Figures in parentheses are numbers of chickens used. 
results may be due to the different analytical methods, the former being enzymatic and the latter non-enzymatic, since uricase method is specific for the determination of uric acid but non-enzymatic method is not. From the calculation based on the organ weight and the concentrations of uric acid precursors, $\mathrm{CHOU}^{29)}$ proposed that the kidney synthesizes 96,60 and $73 \%$ as much uric acid as does the liver for the 1-, 2- and 7-month-old chickens, respectively. It is possible, however, that uric acid is synthesized much more in the liver than in the kidney because xanthine dehydrogenase, the key enzyme involved in the last step of uric acid synthesis, is present much more in the liver than in the kidney of the chicken ${ }^{30}$ ), and because liver weight is more than 3 times as large as kidney weight as shown in Table 1.

This study was supported in part by Grant-in-Aid for Scientific Research from the Ministry of Education, Culture and Science of Japan (276193).

\section{References}

1) Sonne, J.C., I. Lin and J. M. Buchanan, J. Biol. Chem., 220: 369-378. 1956.

2) Levenberg, B., S. C. Hartman and J. M. Buchanan, J. Biol. Chem., 220: 379-389. 1956.

3) ReEm, G. H., J. Biol. Chem., 243: 5695-5701. 1968.

4) Reem, G. H., J. Clin. Invest., 51: 1058-1062. 1972.

5) ReEM, G. H., J. Biol. Chem., 249: 1696-1703. 1974.

6) Okumura, J. and I. Tasaki, J. Nutr., 97: 316-320. 1969.

7) Hevia, P. and A. J.Clifford, J. Nutr., 107: 959-964. 1977.

8) TASAKI, I. and J. OKUMURA, J. Nutr., 83: 34-38. 1964.

9) Teekell, R.A., C.E. Richardson and A.B. Watts, Poultry Sci., 47: 1260-1266. 1968.

10) Iто, R. and K. Tsushima, J. Biochem., 75: 715-721. 1974.

11) Karasawa, Y., I. Tasaki, H. Yokota and F. Shibata, J. Nutr., 103: 526-529. 1973.

12) Katunuma, N., Y. Matsuda and Y. Kuroda, Adv. Enz. Reg., 8: 73-81. 1970.

13) Horn, G.W. and W. R. Featherston, J. Nutr., 102: 489-494. 1972.

14) Nesheim, M.C., J. D. Garlick and D. T. Hopkins, J. Nutr., 78: 89-94. 1962.

15) Dubbs, C. A., F. W. Davis and W.S. Adams, J. Biol. Chem., 218: 479-504. 1956.

16) Pudelkiewicz, W. J., W. W. Sturz and L. D. Matterson, Poultry Sci., 47: 1274-1277. 1968.

17) Goldstein, L., Amer. J. Physiol., 210: 661-666. 1966.

18) ОкuDA, H. and S. FuJII, Saishin Igaku., 21: 622-627. 1966 (In Japanese).

19) Karasawa, Y., Jap. J. Zootech. Sci., 49: 450-457. 1978.

20) Selinger, O.Z. and F. De Balbian Verster, J. Biol. Chem., 237: 2836-2844. 1962.

21) Okumura, J., Y. Karasawa and I. Tasaki, Jap. Zootech. Sci., 44: 122-124. 1973.

22) Featherston, W. R. and R. A. Freedland, J. Nutr., 103: 625-634. 1973.

23) Karasawa, Y. and I. Tasaki, Comp. Biochem. Physiol., 49B: 561-566. 1974.

24) Wilson, R.P., A. A. Letter, R. A. Bioomfield, L. E. Davis and M. E. Mucher, J. Anim. Sci., 25: 1274-1275 (Abstract). 1966.

25) Ö́ström, Å., M. Örström, H. A. KrebS and L. V. EgGLeston, Biochem. J., 33: 995-999. 1939.

26) Karasawa, Y. and I. Tasaki, J. Nutr, 103: 1727-1730. 1973.

27) Karasawa, Y., J. Nutr., 107: 1147-1152. 1977.

28) Karasawa, Y., Comp. Biochem. Physiol., 59A: 367-368. 1978.

29) Chou, S. T., Can. J. Physiol. Pharmacol., 50: 936-939. 1972.

30) Fisher, J. R., J.L. Curtis and W. D. Woodward, Develop. Biol., 15: 289-299. 1967. 


\title{
蛋白質含量の異なる飼料を摃取したニワトリに おける肝グルタミン合成醉素活性と血液 および組織のグルタミンレベル
}

\author{
唐澤豐・堀井雅子・宮沢栄一 \\ 田原幸子・荒牧孝典 \\ 日本獣医畜産大学畜産学科, 武蔵野市 180
}

\begin{abstract}
䀒グルタミン合成酔素の活性と組織のダルタミンレベ ルを，㔻白質レベルが 0, 5,20 あるい注 40\%の飼料を 摄取した体重 $2 \mathrm{~kg}$ 前後の白色レグホーン雄について調 ベた．体重はいずれの飼料を摄取したニワトリでも増加 し，尿の全窒素は飼料の蛋白質レベルの堌加につれて直 線的に增加した. 肝ダルタミン合成醉素活性も同㥞に, 㓷料の蛋白質レベルの堌加とともに直線的に增加した。 去たこのときのアンモニナは，血液と尿ではすべての蛋 白質レベルで，また腎では 5\%以上の蛋白質レベルで直 線的に増加した.したぶって，本突験においてはニワト
\end{abstract}

リのグルタミン生成は飼料蛋白質レベルの增加につれて 增加する之考えられる、しかしながら，グルタミンレベ ルは血槳ではすべての蛋白質レべルで，また肝，腎では 5\%以上の蛋白質レでルで直線的減少した. 一方, 窒素 のおもな給源をグルタミンのアミド窒素とする尿酸は， 血獎，旰，腎抢よび尿で蛋白質摄取量に比例して増加し た. したがって，血漿㧍よび組織のグルタミンレベルが 高蛋白質飼料崖提取したニワトリで低い原因のひとつ はグルタミンを消費する尿酸生成がこのようなニワト リでは活発なためと考えられる. 